\title{
Effect of vitamin A deficiency and Newcastle disease virus infection on IgA and IgM secretion in chickens
}

\author{
BY JAN H. W. M. ROMBOUT ${ }^{1}$, S. REINDER SIJTSMA ${ }^{1,2,3}$, CLIVE E. WEST ${ }^{2}$, \\ YANNOULA KARABINIS ${ }^{1}$, OSCAR K. W. SIJTSMA', AKKE J. VAN DER ZIJPP ${ }^{3}$ \\ AND GUUS KOCH${ }^{4}$ \\ ${ }^{1}$ Department of Experimental Animal Morphology and Cell Biology, Wageningen Agricultural \\ University, PO Box 338,6700 AH Wageningen, The Netherlands \\ ${ }^{2}$ Department of Human Nutrition, Wageningen Agricultural University, PO Box 8129 , \\ 6700 EV Wageningen, The Netherlands \\ ${ }^{3}$ Department of Animal Husbandry, Wageningen Agricultural University, PO Box 338, \\ 6700 AH Wageningen, The Netherlands \\ ${ }^{4}$ Department of Virology, Central Veterinary Institute, PO Box 365, 8200 AJ Lelystad, \\ The Netherlands
}

(Received 18 February 1991 - Accepted 17 December 1991)

\begin{abstract}
The effect of vitamin A deficiency or the lentogenic La Sota strain of Newcastle disease virus (NDV) infection, or both, on immunoglobulin (IgA and IgM) levels in bile and plasma were investigated. In addition, tissue distribution of IgA-, IgG-and IgM-containing cells was studied to establish the source of these Ig. Chickens (1-d-old) with limited vitamin A reserves were fed ad lib. on diets containing either marginal or adequate levels of vitamin A. At 4 weeks of age, half the chickens in each group were infected with NDV. The number of IgA- and IgM-containing cells was not significantly affected by vitamin A deficiency, demonstrating that neither class-switching nor homing of Ig-containing cells is influenced by vitamin A deficiency. Although bile IgM levels were not significantly different in vitamin A-deficient chickens compared with normal chickens, IgA levels were significantly lower. This decrease was even more pronounced in deficient NDV-infected chickens, despite the higher number of IgA-containing cells found in these birds. These results, together with the slightly increased levels of IgA in plasma of vitamin A-deficient chickens, suggest that the hepatobiliary transport of IgA is impaired by vitamin A deficiency and possibly also by NDV infection, although disturbed secretion by IgA-containing cells cannot be excluded.
\end{abstract}

Vitamin A: Newcastle disease: Immunoglobulins: Chickens

Vitamin A deficiency is associated with increased susceptibility to infection and with defects in both natural and acquired defence mechanisms (Scrimshaw et al. 1968; Suskind, 1977). The invading infectious agent itself can also affect host resistance (McChesney \& Oldstone, 1987). The effects of vitamin A deficiency and infection are synergistic (Scrimshaw et al. 1968), which may, at least in part, be caused by concomitant secondary infection. This relationship has been observed in vitamin A-deficient chickens infected with Newcastle disease virus (NDV; Bang et al. 1973). Vitamin A deficiency appears to affect lymphoid cell systems in chickens and, in combination with NDV infection, to cause substantial loss of lymphocytes from the thymus and bursa of Fabricius as well as rapid loss of body-weight (Bang et al. 1973). Recently we have described a model for vitamin A deficiency and NDV infection, in which protein energy malnutrition and secondary infection do not develop (Sijtsma et al. 1989). Using this model decreased numbers of circulating lymphocytes 
(Sijtsma et al. 1991 b), reduced macrophage activity (Sijtsma et al. 1991a) and lowered humoral (Sijtsma, 1989) and cell-mediated immune responses (Sijtsma et al. 1990) were found in vitamin A-deficient chickens. Usually, NDV-infection in combination with vitamin A deficiency resulted in the lowest activities of these defence mechanisms. Since many infectious agents including NDV invade the host via mucosal surfaces, mucosal immunity plays an important role in host resistance (Scicchitano et al. 1988); both systemic and mucosal immune systems are very dependent on the differentiation, distribution and migration of lymphocytes. In systemic lymphoid organs these processes are shown to be affected by vitamin A deficiency (Nauss et al. 1985) and NDV infection (Smith \& Sweet, 1984). So, it can be expected that similar changes would also occur in mucosal-associated lymphoid cells and tissues. Such changes could reduce the relatively high levels of 'background' immunoglobulin (Ig), especially of secretory IgA (van der Heijden et al. 1987), at the mucosal surfaces which normally prevent microbial penetration. Recently, several studies have indicated that vitamin A deficiency might affect mucosal immunity (Sirisinha et al. 1980; McDermott et al. 1982; Takagi \& Nakano, 1983; Puengtomwatanakul \& Sirisinha, 1986; Majumder et al. 1987) but knowledge on the subject is still limited.

In the present paper, the effect of vitamin A deficiency either alone or in combination with NDV infection on the distribution of IgA-, IgG- and IgM-containing cells in lymphoid and mucosal tissues and on $\operatorname{IgA}$ and $\operatorname{IgM}$ levels in bile and plasma is reported.

\section{MATERIALS AND METHODS}

Animals, diets and experimental design

Data were collected from two separate experiments using a similar animal model described in detail by Sijtsma et al. (1989). In brief, female 1-d-old White Leghorn chickens (strain Lohmann Selected Leghorn; Verbeek, Barneveld) obtained as progeny of marginallyvitamin A-deficient laying hens were fed $a d$ lib. on purified diets containing either adequate (1200 retinol equivalents (RE) $/ \mathrm{kg}$ feed) or marginal $(120 \mathrm{RE} / \mathrm{kg}$ feed) amounts of vitamin A. Diets were manufactured as reported in detail by Sijtsma et al. (1989). The chickens were divided equally between two separate air-filtered rooms maintained under reduced pressure, controlled for temperature, relative humidity and light-dark cycles. At the age of $28 \mathrm{~d}$ (Expt 1) or $23 \mathrm{~d}$ (Expt 2), all chickens in one room were intraocularly inoculated with a $10^{8}$ median embryo-infectious dose per bird of the lentogenic La Sota strain of NDV (Delvax; Gist-Brocades, Delft). Control birds in the other room were inoculated with phosphate-buffered saline ( $9 \mathrm{~g}$ sodium chloride/1; PBS). In this way four experimental groups, each housed in one large cage, were formed: groups fed on a diet marginally deficient in vitamin $A$ either non-infected $(A-I-)$ or infected $(A-I+)$, and groups fed on a diet adequate in vitamin $A$ either non-infected $(A+I-)$ or infected $(A+I+)$. Chickens were not vaccinated against any diseases. At the age of $34 \mathrm{~d}$ (Expt 1) or $29 \mathrm{~d}$ (Expt 2), the birds were killed and blood, bile (Expt 2 only) and tissues were collected. The extent of NDV infection was measured with a haemagglutination-inhibition (HI) assay as described previously (Sijtsma et al. 1989). Blood of remaining chickens was used at day 11 of Expt 1 ( $n 9-16)$ and at day 9 of Expt $2(n 6-8)$.

\section{Sampling and preparation of blood, bile and tissues}

Blood was collected from the wing vein in heparinized tubes and, after centrifugation, plasma was stored at $-20^{\circ}$. The birds were then anaesthetized by intraperitoneal injection with Nembutal (CEVA, Paris, France) and weighed. To remove free erythrocytes from the tissues, the birds were perfused with Ringer solution $(0.15 \mathrm{M}-\mathrm{NaCl}, 5.6 \mathrm{~mm}$-potassium 
chloride and $2.25 \mathrm{~mm}$-calcium chloride) until the liver appeared pale. A second perfusion with acid-formol (formaldehyde $(40 \mathrm{ml} / 1)$ and acetic acid $(20 \mathrm{ml} / 1), \mathrm{pH} 2.5)$ was used to fix the tissues in situ. Harderian gland, oesophagus, jejunum, caecal tonsil, caecum, spleen, bursa of Fabricius (Expt 1), and jejunum (Expt 2) were dissected out and post-fixed for $24 \mathrm{~h}$ in acid-formol. Tissues were then rinsed for $24 \mathrm{~h}$ in distilled water, dehydrated, vacuumembedded in Paraplast Plus (Sherwood, UK) and serially sectioned at $5 \mu \mathrm{m}$. Sections were mounted on poly-L-lysine (molecular weight 350000; Sigma Chemical Co., St Louis, MO, USA) coated slides and examined immunohistochemically. In Expt 2, bile was collected from the gall-bladder and stored at $-20^{\circ}$.

\section{Assessment of vitamin $A$ status}

Retinol concentration was measured in plasma using a reversed-phase high-performance liquid chromatographic method modified from that described by Driskell et al. (1982) with retinyl acetate as the internal standard. The results obtained were checked against samples of pooled control sera.

\section{Antibodies}

Details of the antibodies used are listed in Table 1. Monoclonal antibodies were used for immunohistochemistry and polyclonal antibodies for the determination of $\operatorname{IgA}$ and $\operatorname{IgM}$ levels in plasma and bile and for peroxidase $(E C 1.11 .1 .7)$ labelling of the monoclonal antibodies.

\section{Determination of $\operatorname{Ig} A, \operatorname{Ig} M$ and total protein in body fluids}

The concentration of $\operatorname{IgA}$ and $\operatorname{IgM}$ in bile and plasma was determined by a radial immunodiffusion assay (Mancini et al. 1965). Purified biliary IgA (Miles Laboratories Ltd) and serum IgM (Cooper, Biomedical Inc.) were used as standards assuming a molecular extinction coefficient of 14 (Heremans, 1974). All measurements were carried out in duplicate. Protein concentrations were determined according to the method of Lowry et al. (1951) adapted for microtitre plates using bovine serum albumin (BSA) as standard.

\section{Immunohistochemistry}

The immunohistochemical method was based on the principles outlined by Brandtzaeg (1982). After deparaffination and elimination of endogenic peroxidase activity using hydrogen peroxide in methanol $(3 \mathrm{ml} / 1)$, slides were treated with a solution of BSAcontaining PBS $(2 \mathrm{~g} / \mathrm{l})$ to avoid non-specific binding of antibodies. After rinsing with PBS, slides were incubated at room temperature for $75 \mathrm{~min}$ with mouse anti-chicken IgM $(1: 2000)$, IgG $(1: 4000)$ or IgA $(1: 4000)$ monoclonal antibodies and after rinsing subsequently incubated for $60 \mathrm{~min}$ at room temperature with goat anti-mouse: Horseradish peroxidase (HRP) $(1: 100)$. After rinsing, slides were stained according to the 3,3'diaminobenzidine procedure and counterstained slightly with haematoxylin. The following controls were carried out and found to be negative: (1) omission of the first or second incubation with antibodies and (2) blocking of the monoclonal antibodies with either IgA, IgG or IgM (10-20 nmol/ml diluted monoclonal antibodies).

\section{Counting of Ig-containing cells}

The number of IgA-, IgG- or IgM-containing cells was assessed by counting the number of immunoreactive cells in twenty fields $\left(3.2 \mathrm{~mm}^{2}\right.$ in total) which were randomly chosen in representative sections of caecal tonsil, spleen, bursa of Fabricius, and Harderian gland, and in the crypt and basal region of the villi of the oseophagus, caecum, and jejunum. Despite the non-random distribution of Ig-containing cells in the tissues mentioned, the 
Table 1. Description of antibodies used

\begin{tabular}{|c|c|c|c|}
\hline Antibody & Code & Source & $\begin{array}{l}\text { Specification } \\
\text { (reference) }\end{array}$ \\
\hline Goat anti-chicken IgA & - & $\begin{array}{l}\text { Miles Laboratories Ltd, } \\
\text { Stoke Poges, Slough, } \\
\text { UK }\end{array}$ & $\begin{array}{l}\text { Polyclonal against } \\
\text { purified bile IgA }\end{array}$ \\
\hline Goat anti-chicken IgM & - & $\begin{array}{l}\text { Cooper Biomedical Inc., } \\
\text { Malvern, PA, USA }\end{array}$ & Polyclonal \\
\hline Goat anti-mouse/ HRP & P 447 & $\begin{array}{l}\text { Dakopatts, Glostrup, } \\
\text { Denmark }\end{array}$ & $\begin{array}{l}\text { Polyclonal conjugated to } \\
\text { horseradish peroxidase } \\
(E C 1.11 .1 .7)\end{array}$ \\
\hline Mouse anti-chicken IgA & CVI-ChIgA-46.I & $\begin{array}{l}\text { Dr G. Koch, Central } \\
\text { Veterinary Institute, } \\
\text { Lelystad, The }\end{array}$ & $\begin{array}{l}\text { Monoclonal (Jeurissen } \\
\text { et al. 1988) }\end{array}$ \\
\hline Mouse anti-chicken IgG & CVI-ChIgG-47.3 & Netherlands & $\begin{array}{l}\text { Monoclonal (Jeurissen } \\
\text { et al. 1988) }\end{array}$ \\
\hline Mouse anti-chicken IgM & HIS-C12 & $\begin{array}{l}\text { Dr F. G. M. Kroese, } \\
\text { Dept of Histology, } \\
\text { University of Groningen, } \\
\text { Groningen, The } \\
\text { Netherlands }\end{array}$ & $\begin{array}{l}\text { Monoclonal (Jeurissen } \\
\text { et al. 1988) }\end{array}$ \\
\hline
\end{tabular}

counting method chosen appeared to be very reproducible within one section, but also showed a low variation when different sections of one organ were used.

\section{Statistical analysis}

Generally the number of IgA-, IgG- and IgM-containing cells of one organ varied largely between individual birds within one group and, hence, only the arithmetic mean with standard error of the mean (SEM) were calculated. Differences between group means of the concentration of retinol and Ig in plasma, and the Ig content in bile were evaluated with Tukey-honestly significant-difference statistics (Winer, 1971). All procedures were based on the principles outlined by Snedecor \& Cochran (1987) and were performed using a VAX8600 computer with a SPSS-X software package (SPSS, 1984).

\section{RESULTS}

General health

Vitamin A deficiency or NDV infection tended to lower body-weights (Table 2). Only vitamin $A$ deficiency combined with NDV infection $(A-I+)$ resulted in significant lower body-weights compared with control animals $(A+I-)$. However, infected vitamin $A$ deficient chickens $(A-I+)$ were still growing rapidly and their body-weights had not reached a plateau. In both experiments infection with NDV produced mild signs of disease such as tracheal 'rales', diarrhoea and general inactivity, predominantly in vitamin Adeficient chickens. Clinical signs of vitamin A deficiency such as xerophthalmia and ruffled feathers (Sijtsma, 1989) were not observed.

\section{Vitamin A status}

Plasma retinol concentrations were significantly lower in vitamin A-deficient chickens compared with controls (Table 2). Moreover, NDV infection lowered plasma retinol concentration which was significant in the vitamin A-deficient chickens of Expt 1 . 
Table 2. Effect of vitamin $A$ deficiency and Newcastle disease virus infection on bodyweight and plasma retinol concentration of chickens*

(Mean values for no. of animals shown in parentheses)

\begin{tabular}{|c|c|c|c|c|}
\hline \multirow[b]{2}{*}{ Group } & \multicolumn{2}{|c|}{ Body-wt (g) } & \multicolumn{2}{|c|}{ Retinol concentration $(\mu \mathrm{mol} / \mathrm{l})$} \\
\hline & Expt 1 & Expt 2 & Expt 1 & Expt 2 \\
\hline \multicolumn{5}{|l|}{ Mean } \\
\hline \multicolumn{5}{|l|}{ Vitamin A-adequate } \\
\hline Not infected & $367(8)$ & $356(8)$ & $1.79(8)$ & $2 \cdot 53(7)$ \\
\hline \multicolumn{5}{|l|}{ Vitamin A-adequate } \\
\hline Infected & $341(6)$ & $312(8)$ & $1.67(6)$ & $2.00(7)$ \\
\hline \multicolumn{5}{|l|}{ Vitamin A-deficient } \\
\hline Not infected & $339(8)$ & $304(12)$ & $0.50(8)$ & $0 \cdot 48(11)$ \\
\hline \multicolumn{5}{|l|}{ Vitamin A-deficient } \\
\hline Infected & $316(6)$ & $285(12)$ & $0.28(6)$ & $0 \cdot 31(9)$ \\
\hline SD (pooled estimate) & 30 & 31 & $0 \cdot 10$ & 0.36 \\
\hline \multicolumn{5}{|c|}{$\begin{array}{l}\text { Statistical significance (ANOVA) } \\
\text { of main effects of: }\end{array}$} \\
\hline Vitamin A & $P<0.001$ & $P<0.001$ & $P<0.001$ & $P<0.001$ \\
\hline Infection & $P<0.05$ & $P<0.05$ & $P<0.001$ & $P<0.05$ \\
\hline $\begin{array}{l}\text { Statistical significance } \\
\text { (ANOVA) of interaction }\end{array}$ & NS & NS & NS & NS \\
\hline
\end{tabular}

NS, not significant.

* For details of procedures, see pp. 754-756.

\section{HI-antibody titres to $N D V$}

$\log _{2} \mathrm{HI}$ titres were $<4$ in non-infected and 6.5 (SD 1.7) in infected animals of Expt 1 and 4.6 (SD 0.5) in non-infected and 9.3 (SD 0.6) in infected birds of Expt 2. HI titres were not significantly influenced by vitamin A status.

\section{$\operatorname{Ig} A$ and $\operatorname{Ig} M$ concentration in bile and plasma}

As shown in Fig. 1, vitamin A-deficient chickens had a significantly lower IgA concentration in bile than control animals $(\mathrm{A}-\mathrm{I}-v \mathrm{~A}+\mathrm{I}-$ ). NDV infection tended (not significant) to lower biliary IgA levels in both groups. Differences in biliary concentration of IgA could not be attributed to concomitant dilution of bile, because total protein content in bile was not significantly different between groups. In fact, biliary protein content tended to be even higher in vitamin A-deficient or NDV-infected birds; the mean percentage of IgA with respect to total protein was 25 for $\mathrm{A}+\mathrm{I}-, 14$ for $\mathrm{A}+\mathrm{I}+, 10$ for $\mathrm{A}-\mathrm{I}-$ and 6 for $\mathrm{A}-\mathrm{I}+$ chickens. IgM concentrations in bile only tended to be higher, although not significantly, in A - I - birds. Plasma IgA levels were not significantly different but tended to be higher in vitamin A-deficient chickens especially, because these animals appeared to have lower plasma protein concentrations which were even significantly lower in A - I + birds. Plasma IgM levels were not significantly affected by vitamin A deficiency or infection.

Distribution of $\operatorname{Ig} A$-, $\operatorname{Ig} G$ - and $\operatorname{Ig} M$-containing cells

The immunoperoxidase method used appeared to be suitable for detection of cytoplasmic IgA, IgG and IgM (Figs 2 and 3) and, hence, for the discrimination and quantification of IgA-, IgG- and IgM-containing cells (Table 3). Vitamin A deficiency and NDV infection did not result in other locations of the distinct Ig-containing cells studied. In control $(\mathrm{A}+\mathrm{I}-)$ chickens IgA-containing cells appear to be predominant in caecum and jejunum 

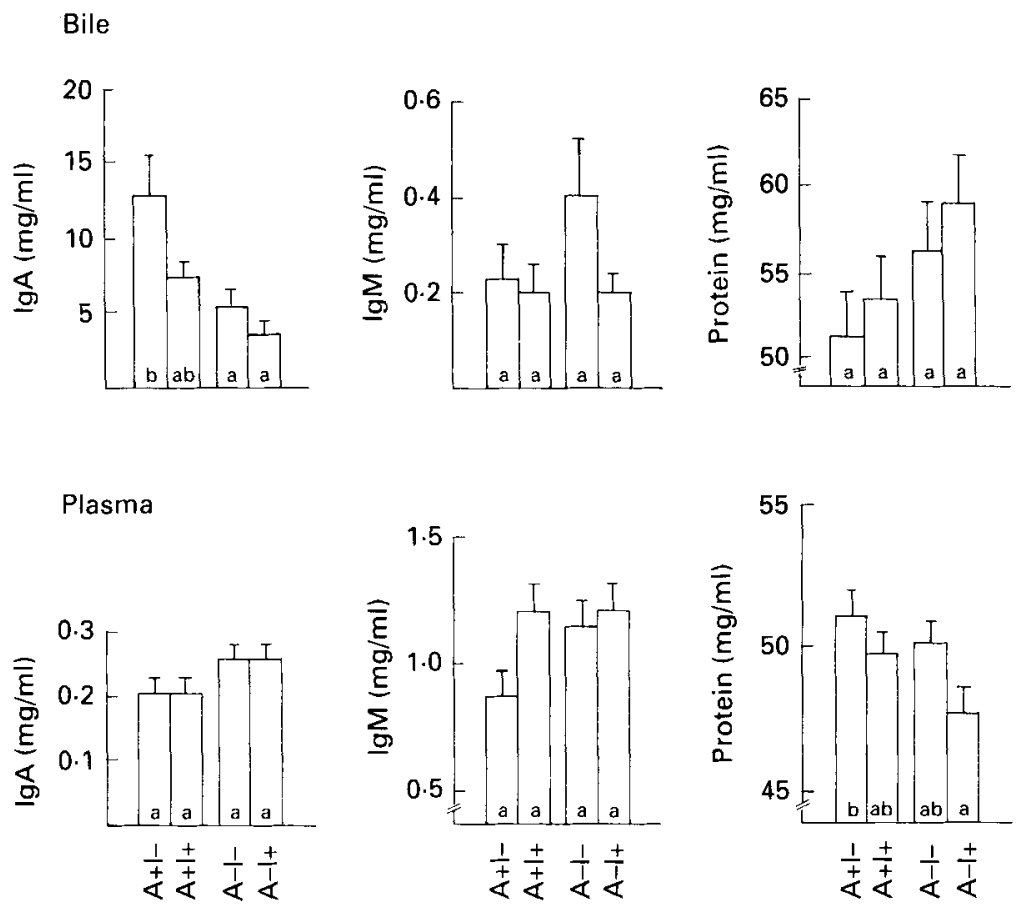

Fig. 1. Effect of vitamin A deficiency and Newcastle disease virus (NDV) infection on immunoglobulin (IgA and IgM) and total protein concentration in bile and plasma of chickens. Values are means with their standard errors represented by vertical bars for eight to twelve chickens/group. Values sharing common superscript letters are not significantly different $(P<0.05$; Tukey). A $+\mathrm{I}-, \mathrm{A}+\mathrm{I}+$, non-infected $(\mathrm{I}-$ ) or infected $(\mathrm{I}+)$ chickens fed on a diet adequate in vitamin $\mathrm{A} ; \mathrm{A}-\mathrm{I}-, \mathrm{A}-\mathrm{I}+$, non-infected or infected chickens fed on a diet marginally deficient in vitamin A. For details of diets and procedures, see pp. 754-755.
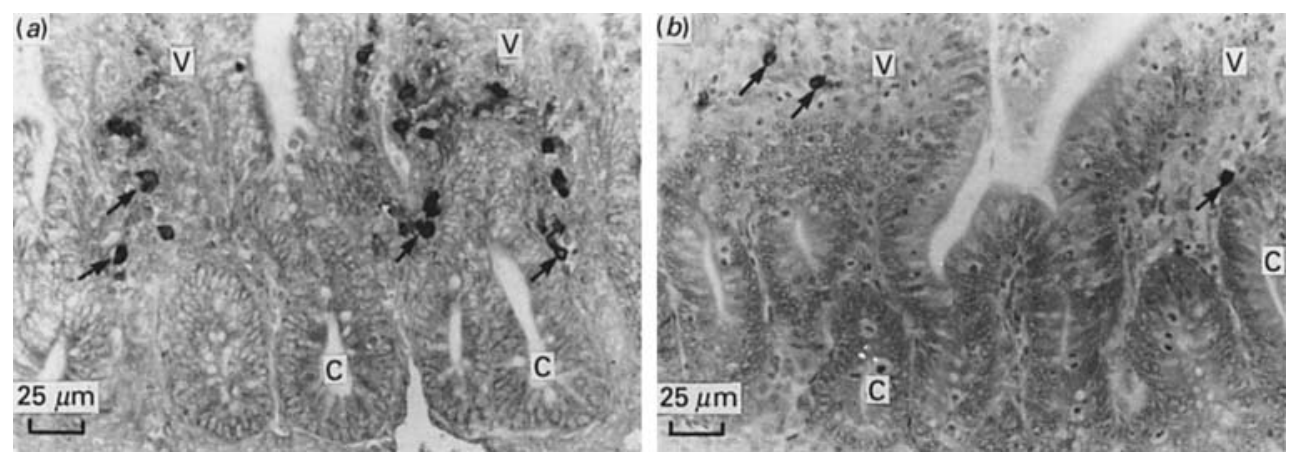

Fig. 2. Immunoperoxidase reactions on sections of jejunum of non-infected chicken fed on adequate vitamin A showing immunoglobulin $((a) \operatorname{IgA}$ and $(b) \operatorname{IgM})$-containing cells $(\uparrow)$, mainly present in the lamina propria of the upper parts of the crypts (C) and lower parts of the villi (V). For details of diets and procedures, see pp. 754-756.

and IgM-containing cells in spleen and bursa of Fabricius. The number of IgG-containing cells was low and never dominated other Ig-containing cells in the tissues investigated. In caecal tonsils both IgA- and IgM-containing cells were abundant, whereas these cells were rarely found in Harderian glands and oesophagus. Significant differences in the number of Ig-containing cells between experimental groups were rarely found, which may be partly 

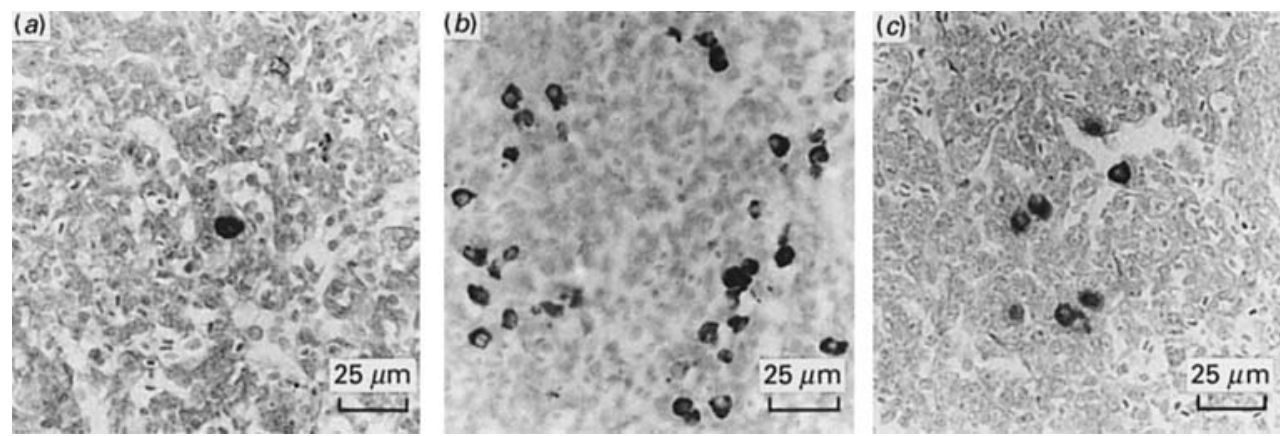

Fig. 3. Immunoperoxidase reactions on sections of spleen of non-infected chickens fed on adequate vitamin $\mathrm{A}$ showing immunoglobulin ( (a) IgA, (b) IgM and (c) IgG)-containing cells. For details of diets and procedures, see pp. 754756 .

the result of the large within-group variation. This variation is illustrated for jejunum in Fig. 4, and was similar in other tissues. Vitamin A deficiency tended to increase the number of IgM-containing cells and to reduce the number of $\operatorname{lgA}$-containing cells, but this effect was mainly due to three of the eight $\mathrm{A}-\mathrm{I}-$ birds having fewer IgA-containing cells and many more IgM-containing cells (Fig. 4). NDV infection resulted in increased numbers of IgA-containing cells in all organs studied, independent of vitamin A status. This increase was only significant in the spleen, and in vitamin A-deficient birds in the caecum and caecal tonsils as well, but this effect can mainly be attributed to the 'IgA-deficient' chickens of the A-I - group. NDV infection also increased the number of IgM-containing cells, particularly in Harderian glands, oesophagus, and spleen. Vitamin A status or NDV infection, or both, did not clearly affect the number of IgG-containing cells.

\section{DISCUSSION}

The present study describes the influence of vitamin A deficiency or infection with a lentogenic strain of NDV, or both, on $\operatorname{IgA}$ and $\operatorname{IgM}$ levels in bile and plasma and on the distribution of Ig-containing cells in lymphoid and mucosal tissues of chickens. The distribution of IgA-, IgG- and IgM-containing cells (mostly plasma cells) in lymphoid organs of normal chickens is comparable with the findings described by Koch \& Jongenelen (1988) using a reversed ELISA spot assay on isolated cells from the same lymphoid organs of 2- and 8-week-old chickens. However, in our study many more Ig-containing cells were found in jejunum and caecal tonsils. Apparently, only a limited number of Ig-secreting cells could be freed from the intestinal tissue. Therefore, immunohistochemistry allows more reliable quantification of intestinal Ig-secreting cells.

In primates, dogs and guinea-pigs most of the gut IgA is transported by the intestinal epithelial cells, while in rats and rabbits the hepatobiliary transport appears to be the major route for transport of $\operatorname{IgA}$ towards the intestinal lumen (Brown \& Kloppel, 1989). For instance, in rats up to $90 \%$ of the intestinal $\mathrm{IgA}$ is transported by hepatocytes, resulting in a concentration in bile of about $2-3 \mathrm{mg} \mathrm{IgA} / \mathrm{ml}$ (Lim et al. 1988). The biliary concentration of $\operatorname{IgA}$ found in the present study $(13 \mathrm{mg} / \mathrm{ml}$ bile of normal chickens) is much higher and roughly similar to concentrations found in birds by others (Rose et al. 1981; Davis \& Sell, 1989). So, in birds, high amounts of IgA appear to be transported by the hepatobiliary route.

Our results have shown that vitamin A deficiency significantly lowered the concentration of IgA in bile (from 25 to $10 \%$ of the total protein concentration), while the mean number 


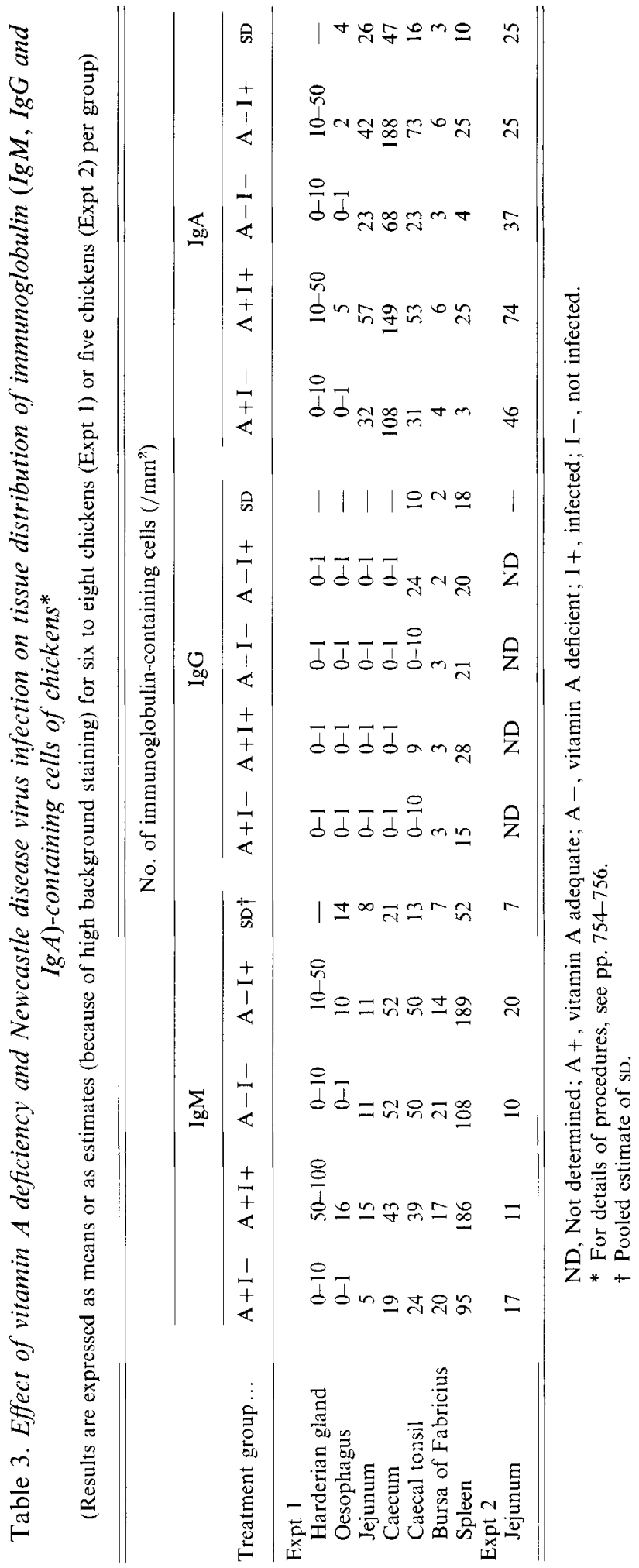




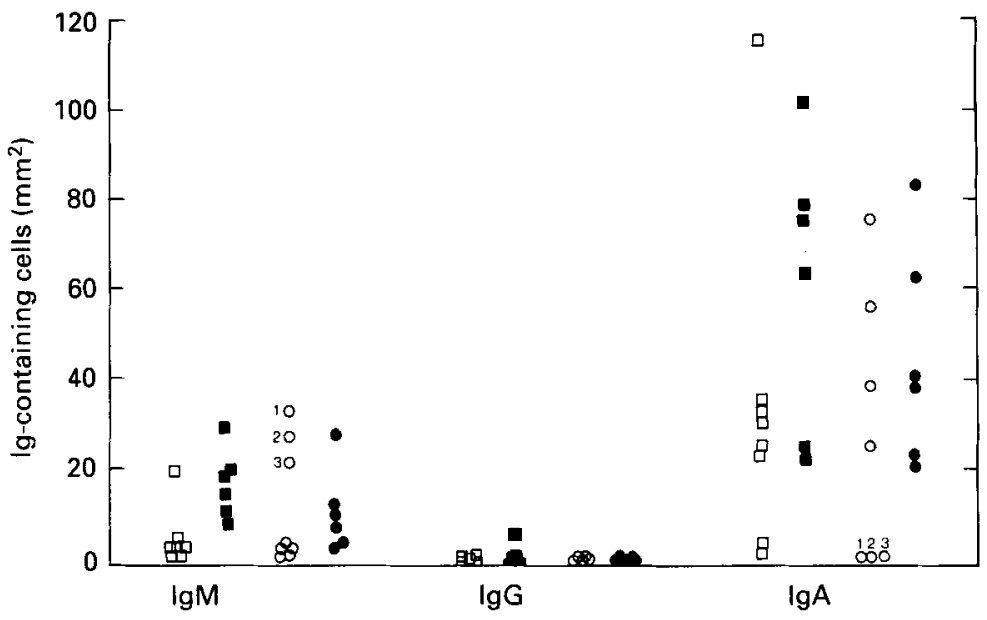

Fig. 4. Effect of vitamin A deficiency and Newcastle disease virus (NDV) infection on immunoglobulin (IgM, IgG and IgA)-containing cells in jejunum (Expt 1), as an example of the large within-group variation observed. Points represent the number of Ig-containing cells per $\mathrm{mm}^{2}$ tissue in one chicken. ( $\square$ ), vitamin $\mathrm{A}$ adequate $(\mathrm{A}+)$, noninfected $(\mathrm{I}-) ;(\mathbf{Q}), \mathrm{A}+$ infected $(\mathrm{I}+) ;(\mathrm{O})$, vitamin $\mathrm{A}$-deficient $(\mathrm{A}-\mathrm{I}-\mathrm{I} ;(\mathbf{O}), \mathrm{A}-\mathrm{I}+, 1,2,3$, Values for chickens in the same group which are IgA-deficient. For details of diets and procedures, see pp. $754-756$.

of IgA-producing cells was hardly affected in the tissues examined. These findings, in addition to the slightly increased plasma IgA levels observed, suggest that hepatobiliary transport of IgA is impaired by vitamin A deficiency. Similar results have been described in vitamin A-deficient rats (Puengtomwatanakul \& Sirisinha, 1986).

Hepatobiliary transport of IgA in mammals (Brown \& Kloppel, 1989), and probably also in chickens (Peppard et al. 1983), is mediated by the secretory component (SC) located on the sinusoidal surface of hepatocytes. Because vitamin A deficiency strongly affects glycoprotein synthesis (Wolf, 1977), the lowered hepatobiliary transport of $\operatorname{IgA}$ in vitamin A-deficient chickens may be explained by impaired synthesis of SC and, hence, decreased IgA-binding capacity. The lower immunofluorescent staining for SC of intestinal epithelial cells in vitamin A-deficient rats (Sirisinha et al. 1980) supports this supposition. However, because plasma IgA levels increased only slightly the impaired SC-mediated hepatobiliary transport of IgA may not be the only effect of vitamin A deficiency. Reduced secretion of IgA by plasma cells should also be considered. On the other hand, Ig secretion was not affected in vitamin A-deficient mice (Lim et al. 1988) and in vitamin A-deficient chickens serum Ig levels were even found to be higher (Davis \& Sell, 1989).

Three A - I - chickens showed practically no IgA-containing cells in the organs studied, but this was compensated for by higher numbers of IgM-containing cells. Because IgA deficiency was not found in $\mathrm{A}-\mathrm{I}+$ birds, this phenomenon must be explained by genetic differences, coincidentally occurring in one group, rather than by disturbed class switching caused by vitamin A deficiency.

NDV infection resulted in higher numbers of IgA-containing cells in all organs observed and of IgM-containing cells in spleen. In addition, NDV infection lowered IgA levels in bile, although not significantly. However, considering the higher numbers of $\operatorname{IgA}$ containing cells and the higher protein concentration in bile of infected birds together with the mild NDV infection used, this decrease cannot be ignored. NDV infection combined with vitamin $A$ deficiency resulted in the lowest $\operatorname{IgA}$ concentration in bile $(6 \%$ of the total protein content compared with $25 \%$ in healthy animals). Recently, Davis \& Sell (1989) also reported significantly lower IgA concentrations in bile of NDV-infected vitamin A-deficient 
chickens, but the contribution of each factor to the decrease in bile IgA could not be given. The possibility that NDV affects bile IgA level indirectly by lowering plasma retinol concentration would appear to be unlikely, because NDV even tended to reduce biliary IgA levels in chickens fed on adequate vitamin A. Although it has been reported that NDV can affect glycoproteins by its neuraminidase (EC 3.2.1.18) activity (Beard \& Hanson, 1984), at present it is unknown whether NDV and vitamin A deficiency affect IgA secretion in the same way.

In conclusion, vitamin A-deficient chickens showed a reduced hepatobiliary transport of IgA. This impairment of the mucosal immune system, together with the epithelia-damaging character of vitamin A deficiency (Wolf, 1977), reduced macrophage activity (Sijtsma et al. 1991 a) and lowered humoral (Sijtsma, 1989) and cell-mediated (Sijtsma et al. 1990) responses of vitamin A-deficient chickens, strongly suggest a much higher susceptibility to infections of these animals. Because hepatobiliary IgA transport seems to be more impaired after a mild NDV infection and NDV alone also causes damaging of epithelia (Alexander \& Allan, 1974), the risk of secondary infection is even larger in A $-\mathrm{I}+$ chickens. Therefore, these results may help to explain the increased susceptibility, severity and duration of infections such as measles, which like NDV belongs to the family Paramyxoviridae (Sijtsma, 1989), in vitamin A-deficient children.

The authors wish to thank Prof. J. G. A. J. Hautvast and Prof. A. Hoogerbrugge for their useful discussions, Mrs M. Coehoorn, Mrs J. J. Taverne-Thiele, Mr R. W. Terluin and $\mathrm{Mr}$ J. W. M. Haas for their help in carrying out the experiments. Thanks are also due to F. Hoffmann-La Roche \& Co, Ltd, Mijdrecht, The Netherlands and Basel, Switzerland for kindly providing the vitamin A preparations.

\section{REFERENCES}

Alexander, D. J. \& Allan, W. H. (1974). Newcastle disease virus pathotypes. Avian Pathology 3, $269-278$.

Bang, B. G., Foard, M. \& Bang, F. B. (1973). The effect of vitamin A deficiency and Newcastle disease on lymphoid cell systems in chickens. Proceedings of the Society for Experimental Biology and Medicine 143, $1140-1146$.

Beard, C. W. \& Hanson, R. P. (1984). Newcastle disease. In Diseases of Poultry, 8th ed., pp. 453-470 [M. S. Hofstad, editor]. Ames, lowa: Jowa State University Press

Brandtzaeg, P. (1982). Tissue preparation methods for immunocytochemistry. In Techniques in Immunocytochemistry, vol. 1, pp. 1-75 [G. R. Bullock and P. Petrusz, editors]. London: Academic Press.

Brown, W. R. \& Kloppel, T. M. (1989). The liver and IgA: immunological, cell biological and clinical implications. Hepatology 9, 763-784.

Davis, C. Y. \& Sell, J. L. (1989). Immunoglobulin concentrations in serum and tissues of vitamin A-deficient broiler chicks after Newcastle disease virus vaccination. Poultry Science 68, 136-144.

Driskell, W. J., Neese, J. W., Bryant, C. C. \& Bashor, M. M. (1982). Measurement of vitamin A and vitamin E in human serum by high-performance liquid chromatography. Journal of Chromatography 231, 439-444.

Heremans, J. F. (1974). Immunoglobulin A. In The Antigens, vol. 2, pp. 365-522 [M. Sela, editor]. New York: Academic Press.

Jeurissen, S. H. M., Janse, E. M., Ekino, S., Nieuwenhuis, P., Koch, G. \& De Boer, G. F. (1988). Monoclonal antibodies as probes for defining cellular subsets in the bone marrow, thymus, bursa of Fabricius, and spleen of the chicken. Veterinary Immunology and Immunopathology 19, 225-238.

Koch, G. \& Jongenelen, I. M. C. A. (1988). Quantification and class distribution of immunoglobulin-secreting cells in mucosal tissues of the chicken. In Histophysiology of the Immune System, pp. 633-639 [S. Fossum and B. Rolstad, editors]. New York: Plenum Press.

Lim, G. M., Sheldon, G. F. \& Alverdy, J. (1988). Biliary secretory IgA levels in rats with protein-calorie malnutrition. Annals of Surgery 207, 635-640.

Lowry, O. H., Rosebrough, N. J, Farr, A. L. \& Randall, R. J. (1951). Protein measurement with the Folin phenol reagent. Journal of Biological Chemistry 193, 265-275.

Majumder, M. S. I., Abdus Sattar, A. K. M. \& Mohiduzzaman, M. (1987). Effect of vitamin A deficiency on guinea pig Peyer's patches. Nutrition Research 7, 539-545.

Mancini, G., Carbonera, A. O. \& Heremans, J. F. (1965). Immunocytochemical quantitation of antigens by single radial immunodiffusion. Immunochemistry 2, 235-254. 
McChesney, M. B. \& Oldstone, M. B. A. (1987). Viruses perturb lymphocyte functions: selected principles characterizing virus-induced immunosuppression. Annual Review of Immunology 5, 279-304.

McDermott, M. R., Mark, D. A., Befus, A. D., Baliga, B. S., Suskind, R. M. \& Bienenstock, J. (1982). Impaired intestinal localization of mesenteric lymphoblasts associated with vitamin A deficiency and protein-calorie malnutrition. Immunology 45, 1-5.

Nauss, K. M., Phua, C.C., Ambrogi, L. \& Newberne, P. M. (1985). Immunological changes during the progressive stages of vitamin A deficiency in the rat. Journal of Nutrition 115, 909-918.

Peppard, J. V., Rose, M. E. \& Hesketh, P. (1983). A functional homologue of mammalian secretory component exists in chickens. European Journal of Immunology 13, 566-570.

Puengtomwatanakul, S. \& Sirisinha, S. (1986). Impaired biliary secretion of immunoglobulin A in vitamin Adeficient rats. Proceedings of the Society for Experimental Biology and Medicine 182, 437-442.

Rose, M. E., Orlans, E., Payne, A. W. R. \& Hesketh, P. (1981). The origin of IgA in chicken bile:its rapid active transport from blood. European Journal of Immunology 11, 561-564.

Scicchitano, R., Stanisz, A., Ernst, P.\& Bienenstock, J. (1988). A common mucosal immune system revisited. In Migration and Homing of Lymphoid Cells, vol. 2, pp. 1-34 [A. J. Husband, editor]. Boca Raton, FL: CRC Press.

Scrimshaw, N. S., Taylor, C. E. \& Gordon, J. E. (1968). Interactions of Nutrition and Infection. WHO Monograph Series no. 57. Geneva: WHO

Sijtsma, S. R. (1989). Vitamin A deficiency and Newcastle disease virus infection in chickens: a model for the study of measles infection in vitamin A-deficient children. PhD Thesis, Agricultural University Wageningen, The Netherlands.

Sijtsma, S. R., Rombout, J. H. W. M., Dohmen, M. J. W., West, C. E. \& van der Zijpp, A. J. (1991 $a$ ). Effect of vitamin A deficiency on the activity of macrophages in Newcastle disease virus-infected chickens. Veterinary Immunology and Immunopathology 27, 17-27.

Sijtsma, S. R., Rombout, J. H. W. M., Kiepurski, A. K., West, C. E. \& van der Zijpp, A. J. (1991b). Changes in lymphoid organs and blood lymphocytes induced by Vitamin A deficiency and Newcastle disease virus infection in chickens. Developmental and Comparative Immunology 15, 349-356.

Sijtsma, S. R., Rombout, J. H. W. M., van der Zijpp, A. J. \& West, C. E. (1990). Vitamin A deficiency impairs cytotoxic $\mathrm{T}$ lymphocyte activity in Newcastle disease virus infected chickens. Veterinary Immunology and Immunopathology 26, 191-201.

Sijtsma, S. R., West, C. E., Rombout, J. H. W. M. \& van der Zijpp, A. J. (1989). The interaction between vitamin A status and Newcastle disease virus infection in chickens. Journal of Nutrition 119, 932-939.

Sirisinha, S., Darip, M. D., Moongkarndi, P., Ongsakul, M. \& Lamb, A. J. (1980). Impaired local immune response in vitamin A-deficient rats. Clinical and Experimental Immunology 40, 127-135.

Smith, H. \& Sweet, C. (1984). The pathogenicity of viruses. In Topley and Wilson's Principles of Bacteriology, Virology and Immunity, vol. 4, 7th ed., pp. 94-123 [F. Brown and G. Wilson, editors]. London: Edward Arnold (Publishers) Ltd.

Snedecor, G. W. \& Cochran, W. G. (1987). Statistical Methods, 8th ed. Ames, Iowa: Iowa State University Press. SPSS (1984). Release 1 of SPSS-X Program. Chicago, IL: SPSS Inc.

Suskind, R. M. (1977). Malnutrition and the Immune Response, pp. 1-468. New York: Raven Press.

Takagi, H. \& Nakano, K. (1983). The effect of vitamin A depletion on antigen-stimulated trapping of peripheral blood lymphocytes in local lymph nodes of rats. Immunology 48, 123-128.

van der Heijden, P. J., Stok, W. \& Bianchi, A. T. J. (1987). Contribution of immunoglobulin-secreting cells in the murine small intestine to the total 'background' immunoglobulin production. Immunology' 62, 551-555.

Winer, B. J. (1971). Statistical Principles in Experimental Design, 2nd ed. New York: McGraw Hill.

Wolf, G. (1977). Retinol-linked sugars in glycoprotein synthesis. Nutritional Reviews 35, 97-99. 